\title{
ENVIRONMENTALAPPROACH OF COMPANIES WITHIN THE PULP/PAPER, METALLURGICAL AND SUGAR/ALCOHOL SECTORS
}

\author{
Laércio Antônio Gonçalves Jacovine ${ }^{1 *}$; Wellerson David Viana²; Ricardo Ribeiro Alves²; \\ Michele Karina Cotta Walter ${ }^{3}$; Márcio Lopes da Silva ${ }^{1}$; Sebastião Renato Valverde ${ }^{1}$ \\ ${ }^{1} U F V$ - Depto. de Engenharia Florestal, Campus Universitário - 36571-000 - Viçosa, MG - Brasil. \\ ${ }_{3}^{2} U F V$ - Programa de Pós-Graduação em Ciência Florestal. \\ ${ }^{3}$ UNICAMP - Programa de Pós-Graduação em Engenharia Agrícola, Cidade Universitária "Zeferino Vaz" - \\ 13083-875 - Campinas, SP - Brasil. \\ *Corresponding author <jacovine@ufv.br>
}

\begin{abstract}
Companies have been witnessing major changes in their environment and environmental models have been developed aiming to improve their strategic planning. The objective of this study was to examine the environmental approach adopted by companies within the Pulp and Paper, Metallurgical and Sugar and Alcohol sectors, in order to evaluate their environmental performances. The analysis was based on a matrix which relates managerial functions with a set of environmental approaches and performance indicators, classifying the company environmental performance as weak, moderate or strong. The managerial functions approached in this model are: Management (General, Legal Affairs, Finance, Human Resources and Purchasing); Product and Process Development; Production and Maintenance; and Marketing. The analyzed indicators include: international insertion; capital origin and location. The pulp and paper and metallurgical companies obtained average scores of 54.5 and 51.56 points, respectively, being classified as having a strong environmental performance. On the other hand, the sugar and alcohol companies obtained average score of 46 points, being classified as moderate in environmental performance. The high level of environmental performance of pulp and paper and metallurgical companies can be attributed to the following factors: larger international insertion, presence of foreign capital in controlling shares, performance in the international market and company location near large population centers. Pulp and paper and mainly sugar and alcohol companies are less efficient in meeting the requirements of the environmental legislation, particularly those related to the conformity of permanent protected areas and legal reserves.
\end{abstract}

Key words: environment, managerial functions, environmental performance

\section{CONDUTAAMBIENTALDE EMPRESAS DOS SETORES DE CELULOSE E PAPEL, SIDERÚRGICO E SUCROALCOOLEIRO}

RESUMO: As empresas têm presenciado transformações amplas no ambiente em que estão inseridas e, com o intuito de auxiliar no planejamento estratégico das empresas, têm sido desenvolvidos modelos ambientais. O objetivo desse estudo foi avaliar a conduta ambiental de empresas dos setores de Celulose e Papel, Siderúrgico e Sucroalcooleiro, de forma a verificar as suas performances em termos ambientais. Essa análise baseou-se em uma matriz que relaciona as funções gerenciais com um conjunto de indicadores de conduta e performance ambiental, classificando a conduta ambiental das empresas como fraca, intermediária ou forte. As funções gerenciais abordadas nesse modelo são: administração (Geral, Jurídica, Financeira, Recursos Humanos e Compras); Pesquisa e Desenvolvimento; Produção e Manutenção; e Marketing. Dentre os indicadores analisados destacam-se: inserção internacional; origem de capital e localização. As empresas de Celulose e Papel e Siderúrgicas apresentaram uma pontuação média de 54,50 e 51,56 pontos, respectivamente, sendo classificadas com uma conduta ambiental forte. Por outro lado, as empresas sucroalcooleiras apresentaram uma pontuação média de 46,00 pontos, que as classificaram com uma conduta ambiental intermediária. O nível mais elevado de performance ambiental apresentado pelas empresas dos setores de Celulose e Papel e Siderúrgico pode ser atribuído aos seguintes fatores: maior inserção internacional, presença de capital estrangeiro no controle acionário, atuação no mercado internacional e localização dessas empresas nas proximidades dos grandes centros populacionais. As empresas de Celulose e Papel e principalmente as sucroalcooleiras são menos eficientes no atendimento aos requisitos da legislação ambiental, particularmente quanto à conformidade das áreas de preservação permanente e de reserva legal.

Palavras-chave: meio ambiente, funções gerenciais, performance ambiental

Sci. Agric. (Piracicaba, Braz.), v.66, n.1, p.1-7, January/February 2009 


\section{INTRODUCTION}

In the last decades companies have been witnessing major changes in their environment. The competitiveness of an organization does not depend on economic factors only, but also on a socially valued management that guarantees its legitimacy and survival in the environmental context. Companies have been seeking to adopt socially responsible postures, occurring therefore a process of continuous renewal, either in the way of operating the business or the management of the organizations (Sanches, 2000; Silva \& Barbosa, 2002; Coutinho \& Soares, 2002).

Environmental models have been developed aiming at aiding the strategic planning of companies, among them, the environmental strategic evaluation model proposed by Abreu (2001) entitled "Structure, Conduct, and Performance - Environmental" (SCP environmental). This model allows the inference of companies' environmental performance, based on the analysis of themselves and their competitors' management, under the pressures of the market in which they operate. The SCP-environmental model seeks to confirm the existence of similar behaviors, which can be grouped according to the environmental management profile, classifying as weak, moderate or strong each managerial function in the company.

The conception of the model is based on the principle that the environmental performance of a firm is a consequence of its competitive practices or patterns of environmental behavior, which in turn, depends on the market structure where it is inserted. In this way, it is therefore important to evaluate the adopted environmental behavior in order to verify the environmental performance of companies of the sectors Cellulose and Paper, Metallurgy and Sugar \& Alcohol. The objectives of this work were to examine the environmental management of companies within these sectors, to evaluate their performance in environmental terms, as well as to analyze the determinant factors that could influence this performance, based on the SCP environmental model.

\section{MATERIALAND METHODS}

\section{Definition of studied companies and sectors}

Companies from the Southeast Region of Brazil, within the pulp and paper and metallurgical sector, representing the forest sector, and sugar and alcohol sector, representing the agricultural sector, were chosen as object study. The metallurgical sector is a large consumer of charcoal originated from planted forests. The Southeast region was chosen for holding the largest number of companies in the referred sectors.
The three sectors were chosen on the basis of criteria such as production chain integration and similarity in the use of natural resources; from raw material acquisition to production processes, as these sectors adopt integration along the production chain, from raw material acquisition (eucalyptus for firms of cellulose and paper and charcoal-based siderurgy and sugar-cane for firms of the sugar-alcohol sector) to the production process, and the acquisition of natural resources cause similar environmental impacts on the set of components acting on the subsystems of the cropping system (planting or ratoon, development and harvest), the main operations (soil management and/ or replanting, maintenance and manual and/or mechanical harvesting), the use of techniques and technologies (amendment fertilizers and pest control using insecticides and herbicides) and the production process (water use, energy use, pollutant emission, effluent discharge, solid residue production).

The companies in this study should meet two criteria considered important for the comparison among the sectors. Companies working in a vertically integrated production system gain the control of all the operations inherent to its product, being possible to trace their environmental management starting from the wood production or land cultivation until the final product is processed in their industries. Companies that are similar regarding the use of natural resources would facilitate the comparison of environmental managements, which is objective of this work. The companies are similar for working with renewable resources, such as wood and sugar cane.

\section{Questionnaire design}

A questionnaire was designed based on the indicators that compose the matrix of environmental conduct characteristics, proposed by Abreu (2001). This matrix has the managerial functions in the rows, the weak, moderate or strong environmental management in the columns, and the characteristics related to the interaction row $\mathrm{x}$ column in the interior of the matrix. The questionnaire consisted of twenty one questions about the managerial functions Management (General, Legal Affairs, Finance, Human Resources and Purchasing); Product and Process Development; Production and Maintenance; and Marketing.

These functions were analyzed to evaluate which are allocated with more or less effort from the assessed companies. The other questions were complementary to the matrix, helping to identify possible contradictory answers.

A survey of the studied companies was carried out by researching the unions and associations to which they were associated. Of the 155 questionnaires 
sent to the sugar and alcohol companies, 32 to the metallurgical companies and 26 to the pulp and paper companies (populations of the sectors), $7.1 \%, 28.1 \%$ and $30.8 \%$ were returned, respectively (Table 2). These return percentages met the minimum sample size, moderately rigorous, recommended by the guidelines for sample size definition according to Little (1997), apud Jacovine (2000), that are $7.0 \%$ for the sugar-alcohol sector and $20.0 \%$ for the siderurgy and cellulose and paper.

The returned questionnaires were validated through the recognition of the respondent, who should be responsible for the environmental area, confirming whether, in fact, there is in the firm a person in charge and/or an environmental department in its organizational structure. All the questions related to the management functions were validated through supplementary questions that attested the veracity of the answers. Nonvalidated questions were not verified.

\section{Stratification system}

The stratification system for each managerial function used the following scoring system: 1 point for weak environmental management; 2 points for moderate management; and 3 points for strong management. Company stratification based on the presented results used the following limits: weak environmental management: from 21 to 34.5 points; moderate from 35 to 48.5 points; and strong from 49 to 63 points. The adopted criteria allow a certain similarity among the companies within the sectors and facilitate their comparison among sectors, and, the criterion vertical production is generally present in larger companies.

The limits presented in Table 1 were used for the analysis of managerial functions. The interval of each management strength is 0.66 . In cases of more than one question per function, it was considered enough to multiply it by the total. For the purpose of the analysis, the average score obtained for each sector was calculated, and, thereafter, the environmental output for each function was evaluated on the basis of the limits defined above.

Indicators used to evaluate management functions

As for the management function Legal Management, the following indicators were analyzed: Knowledge on Environmental Legislation (EL); Keep-

Table 1 - Scoring limits for the classification of environmental management for each managerial function.

\begin{tabular}{lccccc}
\hline Manegerial functions & Number of Questions & Weak & \multicolumn{2}{c}{ Moderate } & Strong \\
\hline General Management & 4 & 4.00 to 6.67 & 6.68 to 9.35 & 9.36 to 12.00 \\
Leagal Affairs Management & 2 & 2.00 to 3.33 & 3.34 to 4.67 & 4.68 to 6.00 \\
Finance Management & 3 & 3.00 to 5.00 & 5.01 to 7.01 & 7.02 to 9.00 \\
Human Resources Management & 1 & 1.00 to 1.66 & 1.67 to 2.33 & 2.34 to 3.00 \\
Product and process development & 1 & 1.00 to 1.66 & 1.67 to 2.33 & 2.34 to 3.00 \\
Purchasing Management & 1 & 1.00 to 1.66 & 1.67 to 2.33 & 2.34 to 3.00 \\
Production and Maintenance & 5 & 5.00 to 8.33 & 8.34 to 11.67 & 11.68 to 15.00 \\
Marketing Management & 4 & 4.00 to 6.67 & 6.68 to 9.35 & 9.36 to 12.00 \\
\hline
\end{tabular}

Table 2 - Scores obtained by each company and average obtained by each sector and classification of management.

\begin{tabular}{|c|c|c|c|c|c|c|}
\hline \multirow{2}{*}{ Companies } & \multicolumn{2}{|c|}{ Pulp and paper } & \multicolumn{2}{|c|}{ Metallurgical } & \multicolumn{2}{|c|}{ Sugar/alcohol } \\
\hline & Score & Management & Score & Management & Score & Management \\
\hline A & 59 & Strong & 63 & Strong & 59 & Strong \\
\hline $\mathrm{B}$ & 57 & Strong & 58 & Strong & 54 & Strong \\
\hline $\mathrm{C}$ & 57 & Strong & 56 & Strong & 52 & Strong \\
\hline $\mathrm{D}$ & 57 & Strong & 55 & Strong & 51 & Strong \\
\hline $\mathrm{E}$ & 54 & Strong & 51 & Strong & 48 & Moderate \\
\hline $\mathrm{F}$ & 53 & Strong & 49 & Strong & 46 & Moderate \\
\hline G & 52 & Strong & 47 & Moderate & 46 & Moderate \\
\hline $\mathrm{H}$ & 46 & Moderate & 45 & Moderate & 39 & Moderate \\
\hline I & & & 40 & Moderate & 38 & Moderate \\
\hline $\mathrm{J}$ & & & & & 37 & Moderate \\
\hline $\mathrm{L}$ & & & & & 36 & Moderate \\
\hline Score verage & & 54.50 & & 51.56 & & 46.00 \\
\hline
\end{tabular}


ing up with the Environmental Legislation; Legal compliance with the Environmental Legislation in Areas of Permanent Preservation and Legal Reserve, in compliance with the Environmental Legislation. The firms of this sector adopted an intermediate environmental behavior, since most firms only partially know the EL, keep up with the EL in a non-systematic way and have PPA and Legal Reserve in compliance with the EL.

For the management function Financial Management the following indicators were analyzed: Definition of volume of investment; Percentage invested in Environment; and Financial return of environment investment. In this way, the firms of this sector adopt an intermediate environmental behavior, because most firms define the volume of investment in order to comply with the Environmental Legislation and in the internally generated projects in a spontaneous way; the percentage invested in environment is between $1 \%$ and $2 \%$; the financial return is tied to the reduction in waste and commercialization of residues generated from modifications of the production process.

The management function Human Resources Management shows that most firms of the sector adopt an intermediate environmental behavior, as they have environmental education programs toward basic actions. For the management function Procurement Management, most firms of the sector adopt an intermediate environmental behavior, as they adopt, in part, minimum environment requirement standards for their suppliers.

The management function Marketing Management shows that most firms use the customer service system to deal with complaints of the interested parties; do not produce reports on environmental performance; have started to identify competitive advantages with environmental performance and communicate information about environmental issues on a non-regular basis, showing that such firms adopt an intermediate environmental behavior. For the management function "Production and Maintenance", the firms adopt an intermediate environmental behavior, as for most firms the adoption of technologies to reduce environmental impacts is tied to purchase of equipment of lower input consumption.

\section{RESULTS AND DISCUSSION}

\section{Environmental management per sector}

The average scores (Table 2) for companies of the pulp and paper and metallurgical sectors classified them as of strong environmental management ( 54.5 and 51.6 points respectively), according to the limits established by the methodology. On the other hand, the companies of the sugar and alcohol sector had a medium score (46 points) that classifies them as having a moderate environmental behavior. The pulp and paper sector showed the highest concentration of companies $(87.5 \%)$ adopting the strong environmental management, followed by the metallurgical (66.7\%), whereas the sugar and alcohol sector showed higher concentration of companies $(63.6 \%)$ adopting moderate environmental management (Table 3 ). These results indicate that the companies are committed with environmental issues.

\section{Environmental conduct per managerial function}

The managerial functions were classified according to their environmental management based on the score limits established by the methodology (Table 1). The score was obtained with weight 1 for weak, 2 for intermediate, and 3 for strong environmental behavior. The total score was used to obtain a general average to verify the environmental behavior of the firm.

It was clear by the individual analysis of each sector that the importance assigned to each function differs among the sectors (Table 4). In this case, for the pulp and paper sector, eight of the nine functions were classified as of strong environmental management, showing that in these companies the efforts are allocated equally among the managerial functions, which guarantees a good environmental performance. However, for the function Legal Affairs Management, the sector had moderate environmental management, mainly affected by the issue related to the conformity of permanent protected areas and legal reserves. By questioning the total area of the firm's land used for cultivation and the total areas of permanent preservation (PPA) and legal reserve, this demonstrates the difficulty of these companies in complying with this legal requirement, because some of them did not comply with the Brazilian legislation regarding the area established for Legal Reserve. This demonstrates the difficulty of these companies in complying with this legal requirement, which has been the focus of a number of discussions, involving State, companies and the representatives of the civil society. With the current trend of the companies within this sector is to seek forest certification, this problem should be solved in a near future, because forest certification has been demanded by most consumers purchasing from Brazilian companies, particularly those from the external market. Forest certification initially demands compliance to the environmental legislation, which establishes the Permanent Preservation Areas and Legal Reserves.

For the companies within the metallurgical sector, the functions "Purchasing Management" and "Marketing Management" together with the managerial function "Human Resources Management" were clas- 
Table 3 - Environmental management of the companies.

\begin{tabular}{|c|c|c|c|c|c|c|}
\hline \multirow{2}{*}{ Management } & \multicolumn{2}{|c|}{ Pulp and paper } & \multicolumn{2}{|c|}{ Metallurgical } & \multicolumn{2}{|c|}{ Sugar/alcohol } \\
\hline & Freq. & $\%$ & Freq. & $\%$ & Freq. & $\%$ \\
\hline Strong & 7 & 87.5 & 5 & 55.6 & 4 & 36.4 \\
\hline Moderate & 1 & 12.5 & 4 & 44.4 & 7 & 63.6 \\
\hline Weak & 0 & 0.0 & 0 & 0.0 & 0 & 0.0 \\
\hline
\end{tabular}

Table 4 - Average score for each managerial function.

\begin{tabular}{|c|c|c|c|c|c|c|}
\hline \multirow[b]{2}{*}{ Function } & \multicolumn{2}{|c|}{ Pulp and paper } & \multicolumn{2}{|c|}{ Metallurgical } & \multicolumn{2}{|c|}{ Sugar/alcohol } \\
\hline & $\begin{array}{c}\text { Score } \\
\text { Average }\end{array}$ & $\begin{array}{c}\text { Environmental } \\
\text { Management }\end{array}$ & $\begin{array}{c}\text { Score } \\
\text { Average }\end{array}$ & $\begin{array}{c}\text { Environmental } \\
\text { Management }\end{array}$ & $\begin{array}{c}\text { Score } \\
\text { Average }\end{array}$ & $\begin{array}{c}\text { Environmental } \\
\text { Management }\end{array}$ \\
\hline General & 11.00 & Strong & 10.00 & Strong & 9.64 & Strong \\
\hline Legal Affairs & 4.38 & Moderate & 5.67 & Strong & 4.45 & Moderate \\
\hline Finance & 8.50 & Strong & 7.89 & Strong & 7.00 & Moderate \\
\hline Human Resources & 2.88 & Strong & 2.22 & Moderate & 2.18 & Moderate \\
\hline $\begin{array}{l}\text { Product and } \\
\text { Process }\end{array}$ & 2.63 & Strong & 2.89 & Strong & 2.82 & Strong \\
\hline Purchasing & 2.75 & Strong & 2.11 & Moderate & 1.64 & Moderate \\
\hline $\begin{array}{l}\text { Production and } \\
\text { Maintenance }\end{array}$ & 13.38 & Strong & 11.89 & Strong & 10.82 & Moderate \\
\hline Marketing & 10.00 & Strong & 8.78 & Moderate & 7.36 & Moderate \\
\hline
\end{tabular}

sified as of moderate environmental management. This shows that the companies within this sector are allocating less effort in complying with external aspects, which results in inefficiency in communicating with stakeholders (shareholders, customers, community) and in disseminating environmental actions taken, besides, little concern in establishing environmental standards for suppliers. Likewise, companies offer little concern for developing some kind of environmental education program directed to their collaborators and the community, since environmental education will be used to guide their decision-making process. The expression "less effort" of companies with moderate environmental management is a comparison with companies with strong environmental management. In addition, all the questions related to management functions were validated by complementary questions that confirmed the reliability of the answers and the existence of this relationship.

Companies within the sugar and alcohol sector had the functions "Human Resources Management", "Purchasing Management" and "Marketing Management", similarly to the metallurgical sector, along with the functions "Legal Affairs Management", "Finance Management" and "Production and Maintenance" classified as of moderate environmental behavior. These functions include the themes environmental education, consumer service, environmental legislation, environmental investment, environmental management and environmental impact. This shows that the companies are also allocating less effort in developing some kind of environmental education program directed to their collaborators and the community, as well as showing less concern for the environmental variable in their productive process and in the definition, and allocating less financial resources to environmental investments.

\section{Analysis of determinant factors of environmental performance}

The analysis of the determinants of environmental performance described by Maimon (1994), international insertion and capital origin and location, can confirm the influence of these factors on the environmental performance of the studied companies. The indicators mentioned refer to those that need more attention by the firms. The firms have dealt with the others in a balanced way.

International Insertion - Table 5 shows the metallurgical and pulp and paper sectors have the largest export percentage, corresponding to 41.0 and $36.4 \%$, respectively. This confirms the best environmental performance of these sectors, having a larger number of companies with strong environmental management, since they have larger international insertion. These companies are subjected to higher pressure from foreign customers, implying in larger environmental investments. Regarding the sugar-alcohol sector, data are separated because it comprises the production of sugar and alcohol, and it is important to show separately the production and exports of each sector. Despite the 
Table 5 - Production and Export per Sector - Year 2003 (in percentage).

\begin{tabular}{|c|c|c|c|c|}
\hline \multirow{2}{*}{ Sectors } & \multirow{2}{*}{ Pulp and paper } & \multirow{2}{*}{ Metallurgical } & \multicolumn{2}{|c|}{ Sugar/alcohol } \\
\hline & & & Sugar & Alcohol \\
\hline Exports & $36.4^{1}$ & $41.9^{2}$ & $33.0^{3}$ & $4.9^{4}$ \\
\hline
\end{tabular}

${ }^{1}$ Source: Associação Brasileira de Celulose e Papel - BRACELPA (2004); ${ }^{2}$ Source: Instituto Brasileiro de Siderúrgia - IBS (2004); ${ }^{3}$ Source: Departamento Intersindical de Estatística e Estudos Sócio-econômicos - DIEESE (2003); ${ }^{4}$ Source: União da Agroindústria Canavieira de São Paulo - ÚNICA (2003)

lower international insertion, the strong pressure on the cellulose and paper sector, as well as the environmental requirements of interested parties; operational control; environment audits; capital origin and location reflect in the adoption of a more restrictive environmental behavior (strong environmental behavior).

A larger or a smaller international insertion, confirmed by the exports, is not the single determinant of higher or lower environmental performance, but, also the demand of shareholders and consumers (Maimon, 1994). Particular attention must be drawn to the destination of exports, i.e., the main international consumer markets, which differ with regard to environmental demands. In the case of the pulp and paper sector, data from the Pulp and Paper Brazilian Association (BRACELPA, 2004) showed that the main pulp and paper markets are Europe and the US, corresponding approximately to $60.8 \%$ of the exports. In the case of the metallurgical sector, the main consumer market for the Brazilian metallurgical products is Asia, accounting for $42.0 \%$ of the exports, according to data from the Brazilian Institute of Metallurgy (IBS, 2004). It is known that the European and American markets have more rigorous rules in relation to the compliance with environmental standards. In this case, the pulp and paper sector undergoes intense pressure to comply with international environmental standards, since its main consumer markets are Europe and the US, which are more environmentally demanding.

Capital origin and company performance The companies within the pulp and paper sector show larger percentage of foreign controlling shares $(46.7 \%)$ (Table 6). Thus, the highest environmental performance of these companies is determined by their main shareholder demands, which ends up influencing their environmental management and improving their relationship with the environment. On the other hand, the lowest environmental performance of companies within the sugar and alcohol sector is due to a smaller percentage of companies with foreign majority share (5.7\%). The results obtained from Table 2 agree with this analyzed indicator, confirming the highest environmental performance level of the cellulose and paper sector and the lowest level of the sugar \& alcohol sector.
Table 6 - Origin of company capital.

\begin{tabular}{lcc}
\hline Sectors & National & Foreign \\
\hline & 53.3 & 46.7 \\
Pulp and paper & 68.7 & 31.2 \\
Metallurgical & 94.3 & 5.7 \\
\hline Sugar/alcohol & & . \\
\hline
\end{tabular}

Source: BRACELPA (2004), IBS (2004), DIEESE (2003)

Table 7 - Company operation.

\begin{tabular}{lcc}
\hline Sectors & National & Foreign \\
\hline Pulp and paper & 66.67 & 33.33 \\
Metallurgical & 81.25 & 18.75 \\
Sugar/alcohol & 97.14 & 2.86 \\
\hline
\end{tabular}

Source: BRACELPA (2004), IBS (2004), DIEESE (2003)

By adding the two factors (international insertion and capital origin), it can be inferred that the higher environmental performance of pulp and paper and metallurgical companies is determined by their larger insertion in the international market, through their exports and shareholder demands. On the contrary, lower environmental performances of companies within the sugar and alcohol sector, which adopted in their majority a moderate environmental behavior, is determined by a smaller international insertion resulted from smaller export volumes $(37.9 \%$, sugar and alcohol export values) and the demands of their main shareholders, almost all nationals (94.3\%).

The companies within the pulp and paper sector show higher environmental performance, as they have the largest percentage of units operating in other countries (33.3\%) (Table 7). The lowest environmental performance of sugar and alcohol companies, however, is determined by the smallest number of companies operating in other countries $(2.9 \%)$. The adoption of environmental protection occurs more easily in companies that have production units in several countries, as they have more access to technical, managerial and financial resources (Maimon, 1994). Decisions made at corporate level will comprise all the companies, and, therefore, influence their environmental performance. 
Table 8 - Population of cities with production units of the sampled companies.

\begin{tabular}{lcccccc}
\hline \multirow{2}{*}{ Management } & \multicolumn{2}{c}{ Pulp and paper } & \multicolumn{2}{c}{ Metallurgical } & \multicolumn{2}{c}{ Sugar/alcohol } \\
\cline { 2 - 6 } & Freq. & $\%$ & Freq. & $\%$ & Freq. & $\%$ \\
\hline Above 1 million & 1 & 4.2 & 2 & 13.3 & 1 & 1.3 \\
Between 500 thousand and 1 million & 0 & 0 & 0 & 0 & 1 & 1.3 \\
Between 100 thousand and 500 thousand & 9 & 37.5 & 3 & 20.0 & 8 & 10.3 \\
Between 50 thousand and 100 thousand & 7 & 29.2 & 5 & 33.3 & 11 & 14.1 \\
Below 50 thousand & 7 & 29.2 & 5 & 33.3 & 57 & 73.1 \\
\hline
\end{tabular}

Source: BRACELPA (2004), IBS (2004), DIEESE (2003).

These statements can be contested, since some companies may not act in the same manner in all their units, considering, in particular, the market pressures. However, the companies have been adopting corporate policies applied to all units, in order to protect their image (Maimon, 1994).

Company location - Table 8 shows data referring to the population of cities where the production units of the sampled companies are located. In this case, the objective was to evaluate the action of the population around the plants and to examine the influence of the communities on the environmental actions taken by the companies. Most production units of the sampled companies within the pulp and paper and metallurgical sectors (70.8\% and $66.7 \%$ respectively) are located in cities with population above 50 thousand inhabitants, whereas the sugar and alcohol production units $(73.1 \%)$ are located in cities with population below 50,000 inhabitants. Consequently, most of the pulp and paper and metallurgical companies, which are located in cities with larger population, undergo more intense pressure from the society, explaining the higher environmental performance and leading to a strong environmental management. Nevertheless, most of the sugar and alcohol companies located in cities of smaller population undergo less intense pressure from society, which explains their lower environmental performance, and consequently, the concentration of companies that adopt moderate environmental management.

\section{CONCLUSIONS}

The companies of the Cellulose and Paper sector showed better environmental behaviour, which may prove a better environmental performance of these companies compared with the Metallurgical and Sugar $\&$ Alcohol sectors.

Companies of the Metallurgical and Sugar \& Alcohol sectors have not been making efforts to improve their environmental management in relation to Purchase Management, Marketing Management and Human Resource Management.
Companies of the Cellulose and Paper and Sugar \& Alcohol sectors have not been making efforts to improve their environmental management in relation to Juridical Management.

The increased international insertion, foreign capital origin, international performance and proximity to densely populated cities contributed to a higher environmental performance of the Cellulose and $\mathrm{Pa}-$ per sector.

\section{REFERENCES}

ABREU, M.C.S. Modelo de avaliação da estratégia ambiental: uma ferramenta para a tomada de decisão. Florianópolis: Universidade Federal de Santa Catarina, 2001. 232p. Tese (Doutorado).

ASSOCIAÇÃO BRASILEIRA DE CELULOSE E PAPEL BRACELPA. Relatório anual. São Paulo: BRACELPA, 2004. $20 \mathrm{p}$.

COUTINHO, R.B.G.; SOARES, T.D.L.A.M. Gestão estratégica com responsabilidade social: arcabouço analítico para auxiliar sua implementação nas empresas no Brasil. Revista de Administração Contemporânea, v.6, p.75-96, 2002.

DEPARTAMENTO IINTERSINDICAL DE ESTATISTICA E ESTUDOS SÓCIOECONÔMICOS - DIEESE. Situação do setor sucroalcooleiro em 2003. São Paulo: DIEESE, 2003. 26p.

INSTITUTO BRASILEIRO DE SIDERURGIA - IBS. Informações estatísticas brasileiras. Available at: http://www.ibs.org.br/ infbras.htm. Accessed 09 Mar. 2004.

JACOVINE, L.A.G. Gestão da qualidade na colheita de madeira em povoamentos eqúiâneos. Viçosa: Universidade Federal de Viçosa, 2000. 136p. Tese (Doutorado).

LITTLE, A.D. Auditoria de meio ambiente, saúde ocupacional e segurança industrial: fundamentos, habilidades e técnicas. São Paulo: Arthur D. Little, 1997. 270p.

MAIMON, D. Eco-estratégia nas empresas brasileiras: realidade ou discurso? RAE - Revista de Administração de Empresas, v.34, p.119-130, 1994.

SANCHES, C.S. Gestão Ambiental Proativa. RAE - Revista de Administração de Empresas, v.40, p.76-87, 2000.

SILVA, C.L.M.; BARBOSA, S.L. Estratégia, fatores de competitividade e contexto de referência das organizações: uma análise arquetípica. Revista de Administração Contemporânea, v.6, p.7-32, 2002.

UNIÃO DA AGROINDÚSTRIA CANAVIEIRA DE SÃO PAULO UNICA. Available at: http://www.portalunica.com.br. Accessed 09 Nov. 2003.

Received December 21, 2006

Accepted November 14, 2008 